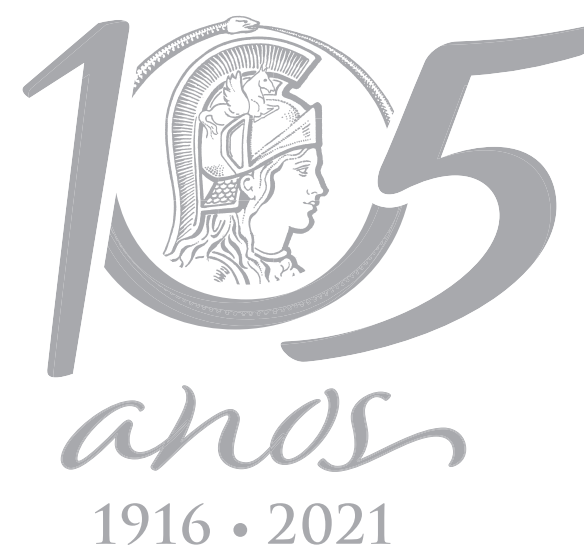

\title{
Antifungal activity of a novel 3-Alkylpyridine analog derived from Marine sponge alkaloids
}

\author{
JÉSSICA T. ANDRADE, WILLIAM G. LIMA, CAMILA S. BARBOSA, ALESSANDRA \\ M.M.N. GONÇALVES, MAYRA K.P. SILVA, FERNANDA B. MORAIS, JULIANA M.C. \\ PALUMBO, GUSTAVO H.R. VIANA \& JAQUELINE M.S. FERREIRA
}

\begin{abstract}
Candida spp. is considered an important cause of healthcare-associated infections worldwide. Currently, the emergence and spread of resistant Candida isolates are being increasingly reported, making the development of new agents urgently needed. In this study, we showed the in vitro anti-Candida activity of seven synthetic 3-alkylpyridine alkaloid analogs. Among them, alkaloid 1 presented a potent antifungal effect, which was independent of its capacity of binding with the fungal membrane ergosterol or cell wall. Analog 1 showed fungistatic and fungicidal effects against $C$. albicans (MIC $7.8 \mu \mathrm{g} / \mathrm{mL}$ and MFC $62.5 \mu \mathrm{g} / \mathrm{mL}$ ), C. glabrata, C. krusei (MIC and MFC 31.2 $\mu \mathrm{g} / \mathrm{mL}$ ), and C. tropicalis (MIC $31.2 \mu \mathrm{g} / \mathrm{mL}$ and MFC $125 \mu \mathrm{g} / \mathrm{mL}$ ). The time kill-curve study showed that compound 1 has a potent fungicidal effect in vitro, eliminating $C$. albicans cells. Furthermore, an in vitro synergistic effect with ketoconazole was observed for compound 1. This compound also eliminated the yeast-to-hypha transition. However, it showed high cytotoxicity against mammalian cells. Taken together, these findings support the use of compound 1 as a prototype to develop new anti-Candida agents, but molecular modifications should be done to minimize the high cytotoxicity obtained.
\end{abstract}

Key words: Antifungal activity, Candida albicans, marine sponge alkaloids, synergistic effect, time-kill assay, 3-Alkylpyridine alkaloid analogs.

\section{INTRODUCTION}

Candida albicans is the most prevalent fungal pathogen in humans; it is associated with severe fungal infections, accounting for more than $90 \%$ of cases of invasive fungal infection (Kauffman 2006, Zida et al. 2016). In addition, this fungus can assume several morphologies, including yeast, hypha, and pseudohypha (Kornitzer 2019). In this context, fungal infections represent a global public health concern. For instance, in the United States, 9\% of healthcareassociated bloodstream infections are caused by Candida spp. (Pfaller \& Diekema 2007, 2010), of which $40-70 \%$ are caused by C. albicans (Falagas et al. 2010, Pfaller et al. 2012, Kornitzer
2019). Furthermore, candidiasis is currently responsible for approximately 700,000 annual deaths worldwide (Bongomin et al. 2017).

Only a few drugs are available to treat fungal infections compared to those available to treat bacterial infections (Carvalho et al. 2018a). To make this scenario even more adverse, the efficacy of the treatment of fungal infections has been compromised by the acquisition of resistance by these pathogens (Pappas et al. 2016). The increase of opportunistic fungal infections raises the need for the design and synthesis of new antifungal agents. In this context, alkaloid derivatives are an important source of novel compounds with pharmaceutical potentials, as they have been described to 
possess various biological activities, such as antiviral (Wang 2006), antitumor (Frenz et al. 2004), antibacterial, antifungal (Wang 2006, Dai et al. 2011, Fyhrquist et al. 2017), and antiparasitic (Hilário et al. 2011, Viana et al. 2016).

Thus, this study aimed to evaluate the anti-Candida spectrum of seven synthetic 3-alkylpyridine alkaloid (3-APA) analogs, which presented antibacterial and antibiofilm activities against relevant bacterial pathogens, such as Klebsiella pneumoniae and Staphylococcus aureus in a previous study (Herrera et al. 2020). Moreover, for the most promising alkaloid, we determined its effect on the fungal membrane ergosterol and cell wall, the anti-virulence activity (i.e., potential to inhibit the yeastto-hypha transition), and the toxicity against mammalian cells using renal lineages (Vero and BHK-21). Additionally, the synergistic effect of this most active compound was studied after its combination with commercial antifungals (ketoconazole and nystatin) against a fluconazole-resistant C. albicans strain.

\section{MATERIALS AND METHODS}

\section{Synthesis}

The synthesis of 3-APA analogs of theonelladin C (compounds 1, 2a-d, 3, and 4) (Figure 1) was performed as previously described by Hilário et al. (2011), Gonçalves et al. (2014), and Barbosa et al. (2018).

\section{Microorganisms}

The fungi used were kindly provided by the Reference Microorganisms Laboratory of Fundação Oswaldo Cruz (FIOCRUZ), Rio de Janeiro, Brazil, and were originated from the American Type Culture Collection (ATCC). The antifungal activity was investigated against $C$. albicans ATCC 10231, C. albicans ATCC 18804, C. glabrata ATCC 2001, C. krusei ATCC 34135, and C. tropicalis ATCC 28707.

In addition, eight clinical isolates of $C$. albicans were employed in this study (i.e., five isolates originated from vaginal secretions (Dra. Magna Paiva collection), and three isolates from swabs of the oral cavity (Dra. Susana Johann collection)). The identification of all C. albicans clinical isolates was performed using molecular<smiles>COC(=O)CCN(CCCOCCCc1ccc[n+](Cc2ccccc2)c1)CCCOC(=O)OCc1cccnc1</smiles><smiles>OCCCOCCCc1cccnc1</smiles><smiles>N#C[14CH2][14CH2]COCCCc1cccnc1</smiles>

Figure 1. The 3- alkylpyridine alkaloid (3-APA) analogs 1, 2a-d, 3, and 4. 
assays. The isolates were kindly provided by the Universidade Federal de Minas Gerais.

\section{Antifungal assay}

\section{Inoculum preparation}

The fungal inoculum was prepared according to document M27-A3 of the Clinical Laboratory and Standard Institute (CLSI 2008). Candida strains were grown in Sabouraud-dextrose (SD) agar (Acumedia, USA) for $48 \mathrm{~h}$, and isolated colonies were suspended in saline solution $(0.85 \% \mathrm{NaCl}$; Synth, Brazil). The density of the resultant suspension was adjusted according to the 0.5 McFarland standard corresponding to $10^{6}$ colony-forming units $/ \mathrm{mL}(\mathrm{CFU} / \mathrm{mL})$. Then, the fungal solution was diluted in SD broth (Acumedia, USA) to a concentration of $1.5 \times 10^{3}$ $\mathrm{CFU} / \mathrm{mL}$.

\section{Determination of minimum inhibitory concentration (MIC)}

The efficacy of seven synthetic alkaloids was examined against Candida spp. by the broth microdilution method, following the M27-A3 document of the Clinical and Laboratory Standard Institute (CLSI 2008), with minor modifications (Andrade et al. 2018). Briefly, each alkaloid was dissolved in dimethyl sulfoxide (DMSO; 2 \% v/v; Sigma-Aldrich, USA) for stock solution preparation in concentrations ranging from 1.9 to $500 \mu \mathrm{g} / \mathrm{mL}$. Then, the plates were incubated at $35 \pm 2{ }^{\circ} \mathrm{C}$ for $48 \mathrm{~h}$, and the MICs were defined as the lowest concentration of compounds that inhibited the visible growth of yeast. DMSO ( $2 \% \mathrm{v} / \mathrm{v}$; Sigma-Aldrich, USA) was used as the solvent control. In addition, ketoconazole (Pharmanostra, Brazil) or nystatin (Pharma Nostra, Brazil) were included as the positive control $(0.97-500 \mu \mathrm{g} / \mathrm{mL})$. The assay was performed in triplicate in three independent experiments.

\section{Determination of minimum fungicidal concentration (MFC)}

The MFC is considered the lowest concentration of antifungal agent that reduces the viability of the initial fungal inoculum by $99.9 \%$ (Lyu et al. 2016, Carvalho et al. 2018b). Briefly, $10 \mu \mathrm{L}$ of samples from each well that did not show any visible growth in the MIC assay was plated on SD agar (Acumedia, USA) and incubated at $35 \pm$ $2{ }^{\circ} \mathrm{C}$. The solvent (DMSO $<2 \% \mathrm{v} / \mathrm{v}$ ) and positive controls (nystatin and ketoconazole) were also tested. The assay was performed in triplicate in three independent experiments.

\section{Time-kill curve}

The time-kill curve assay was performed for the most active alkaloid, as previously described (Zore et al. 2011). Briefly, tubes with $10 \mathrm{~mL} \mathrm{SD}$ broth containing C. albicans ATCC $10231\left(10^{6}\right.$ $\mathrm{CFU} / \mathrm{mL}$ ) and different concentrations of the most active alkaloid were incubated at $35 \pm 2$ o C. Then, $0.1 \mathrm{~mL}$ from these tubes were taken at different time intervals $(0,4,8,12,24,36$, and $48 \mathrm{~h}$ ), inoculated on SD agar, and incubated at $35 \pm 2^{\circ} \mathrm{C}$ for $48 \mathrm{~h}$ for posterior colonies count (i.e., determination of $\mathrm{CFU} / \mathrm{mL}$ ). Ketoconazole $(125 \mu \mathrm{g} / \mathrm{mL})$ and DMSO (<2\% v/v) were used as positive and solvent controls, respectively.

\section{Checkerboard assay}

The checkerboard microtiter plate assay was used to determine the effect of the combination of the most active alkaloid derivative with commercially available antifungals (ketoconazole and nystatin) (Carvalho et al. 2018b, Lima et al. 2019). Briefly, the alkaloid that showed the most promising activity in the MIC assay was tested at concentrations ranging 
from 1.9 to $125 \mu \mathrm{g} / \mathrm{mL}$. Solutions of ketoconazole and nystatin at the same concentrations were combined in a 1:1 ratio to evaluate the antifungal effect resulting from their interaction with the alkaloid. The fractional inhibitory concentration index $(\mathrm{FICl}$ ) was determined by the sum of the ratios of the MIC of the sample alone and the MIC of the combinations. For the interpretation of the results, the effect was considered synergistic $(\mathrm{FICl} \leq 0.5)$, additive $(0.5 \leq \mathrm{FICl} \leq 1.0)$, indifferent $(1.0 \leq \mathrm{FICl} \leq 4.0)$, or antagonism ( $\mathrm{FICl} \geq 4.0)$ (Carvalho et al. 2018b, Lima et al. 2019).

\section{Phenotypic effects of the alkaloid on fungal cells}

\section{Exogenous ergosterol binding assay}

The MIC of the most active alkaloid derivative against C. albicans, C. krusei, C. glabrata, and C. tropicalis was determined in the absence and presence of exogenous ergosterol $(200 \mu \mathrm{g} / \mathrm{mL}$; Sigma, USA) (Escalante et al. 2008). Nystatin (Phamanostra, Brazil; 2.0 to $500 \mu \mathrm{g} / \mathrm{mL}$ ), an antifungal that acts on the ergosterol of the fungal membrane, was used as the positive control.

\section{Sorbitol assay}

The effect of the most active alkaloid derivative on the cell wall of C. albicans, C. krusei, C. glabrata, and C. tropicalis was evaluated by the determination of the MIC in the presence of sorbitol (0.8 M; Synth, Brazil), which is a known osmotic protector of the fungal wall cell (Escalante et al. 2008). Caspofungin (Sigma, USA; 0.0625 to $62.5 \mu \mathrm{g} / \mathrm{mL}$ ), an antifungal that acts on the fungal wall, was used as the positive control.

\section{Inhibition of Candida yeast-to-hyphae (y-h) transition}

The ability of the most active alkaloid (in MIC and MFC assays) to inhibit the $\mathrm{Y}-\mathrm{H}$ transition was evaluated according to Andrade et al. (2018). Briefly, hyphae induction was conducted by incubating C. albicans ATCC 10231 ( $10^{3}$ CFU/mL) in a microplate containing fetal bovine serum (FBS) and different alkaloid concentrations. The microplates were incubated for 24,48 , and $72 \mathrm{~h}$ at $35 \pm 2{ }^{\circ} \mathrm{C}$, and the morphology of the Candida cells was visualized using a Nikon TE 2000U Eclipse microscope equipped with a DC300 F digital imaging system (Leica Microsystems, Germany) with a magnification of 400x. Positive (ketoconazole) and solvent (DMSO 2\% v/v) controls were included (Araújo et al. 2013, Andrade et al. 2018).

\section{Cell culture and cytotoxicity assay}

The cytotoxicity of the most active alkaloid was evaluated using Baby Hamster Kidney (BHK, ATCC CCL-10) and African green monkey kidney epithelium (Vero, ATCC CCL-81) cells. The cells were cultured in Dulbecco's Modified Eagle Medium supplemented with 10\% FBS and 0.3\% solution containing penicillin, streptomycin, and amphotericin B. Cell cultures were maintained at $35 \pm 2$ o $\mathrm{C}$ in a humidified atmosphere of $5 \%$ $\mathrm{CO}_{2}$. Cells lines were exposed to the alkaloid for $48 \mathrm{~h}$, and the cell viability was quantified by the 3-(4.5-dimethylthiazol-2-yl)-2.5diphenyltetrazolium bromide (MTT) colorimetric assay (Twentyman \& Luscombe 1987). Finally, the cytotoxic concentrations for $50 \%$ of the cells $\left(\mathrm{CC}_{50}\right)$ were calculated by linear regression analysis (Souza et al. 2013). In addition, the selectivity index (SI) value was determined by the ratio of the $\mathrm{CC}_{50}$ and the MIC (antifungal assay), indicating the specificity of compounds toward pathogens and mammalian cells. Larger 
SI values indicate greater cell selectivity (Souza et al. 2013).

\section{RESULTS AND DISCUSSION}

The antifungal potential of seven synthetic 3-alkylpyridine alkaloid (3-APA) analogs was evaluated against several Candida species frequently involved in invasive candidiasis (Table I). Among them, alkaloid 1 presented fungistatic and fungicidal activities against all Candida species evaluated (MIC ranging from 7.8 to 31.25 $\mu \mathrm{g} / \mathrm{mL}$ and MFC ranging from 31.25 to $125 \mu \mathrm{g} / \mathrm{mL}$ ), revealing an extended spectrum of action that covers the most frequent species involved in candidiasis. This fungicidal activity of compound 1 against all Candida species evaluated is relevant because substances that kill pathogens are strong candidates for clinical use (Wong et al. 2014). In addition to the antifungal activity against reference strains of Candida spp., this alkaloid also showed a considerable effect on clinical specimens of different origins (Table I). Herein, compound 1 presented fungistatic and fungicidal activity against all oral (MIC $7.8 \mu \mathrm{g} /$ $\mathrm{mL}$; MFC range of $31.25-125 \mu \mathrm{g} / \mathrm{mL}$ ) and vaginal (MIC $7.8 \mu \mathrm{g} / \mathrm{mL}$; MFC range of $31.25-62.5 \mu \mathrm{g} / \mathrm{mL}$ ) isolates of $C$. albicans tested.

In addition, the alkaloid $2 \mathrm{~d}$ showed activity against all reference strains of Candida spp. employed in this study (MIC range of 15.6-62.5 $\mu \mathrm{g} / \mathrm{mL}$; MFC range of 62.5-125 $\mu \mathrm{g} / \mathrm{mL}$ ), mainly against C. krusei (MIC $15.6 \mu \mathrm{g} / \mathrm{mL}$ ), an intrinsically azole-resistant species (Carvalho et al. 2018b). This alkaloid also showed antifungal activity against three oral and three vaginal isolates of C. albicans (MIC ranging from 31.25 to $62.5 \mu \mathrm{g} / \mathrm{mL}$ and MFC ranging from 62.5 to $250 \mu \mathrm{g} / \mathrm{mL}$ ). Similar to these results, Dai et al. (2011) evaluated five synthetic alkaloids that showed fungistatic and fungicidal activity against C. albicans, C. glabrata, and C. krusei, with MIC and MFC ranging from 7.8 to $15 \mu \mathrm{g} / \mathrm{mL}$. Furthermore, Rane et al. (2012) showed the potential antifungal activity of 20 synthetic compounds derived from marine alkaloids against C. albicans (MIC ranging from 1.56 to $12.5 \mu \mathrm{g} / \mathrm{mL}$ ). Besides that, another study conducted by Fyhrquist et al. (2017) showed the potential antifungal activity of natural alkaloids against C. albicans and C. glabrata, with MIC of $5,37 \mu \mathrm{g} / \mathrm{mL}$. Thus, the results presented in this study corroborate those of previous works that point to alkaloids as a promising class in the development of prototypes for antifungal therapy.

Except for compounds 1 and 2d, all other alkaloids evaluated showed low antifungal activity (MIC of $125-500 \mu \mathrm{g} / \mathrm{mL}$ ) (Table I). In contrast to the analogs evaluated, compound 1 has one counterion $\left(\mathrm{Cl}^{-}\right)$, which was important for its antifungal activity. As described by Viana (2008), the counterion counterbalances the positive charge of the nitrogen group and plays an essential role in reducing the MIC values. Moreover, the alkaloid $2 \mathrm{~d}$ was synthesized by the insertion of a long carbon chain into its structure. In this context, studies indicate that long chains appear to be important for the antimicrobial activity of alkaloids (Pernak et al. 2001, Viana 2008).

The time-kill kinetics assay showed that after $8 \mathrm{~h}$ of exposure to alkaloid 1 (62.5 $\mu \mathrm{g} / \mathrm{mL}$ ), a maximum fungicidal effect was observed, resulting in the complete elimination of C. albicans. In addition, compound 1 at MIC $(31.25 \mu \mathrm{g} / \mathrm{mL})$ reduced in three logs the fungal load after $48 \mathrm{~h}$ of incubation (Figure 2). Ketoconazole did not show a fungicidal effect, which is in accordance with its known fungistatic effect (Hawser \& Islam 1999). The growth control continued to grow throughout the experiment $(48 \mathrm{~h})$, and no reduction in fungal load was observed with DMSO treatment, 


\begin{tabular}{|c|c|c|c|c|c|c|c|c|c|c|c|c|c|c|}
\hline \multirow{2}{*}{$\frac{n}{2}$} & $\stackrel{\tilde{u}}{\Sigma}$ & $\stackrel{\circ}{\underset{f}{f}}$ & $\stackrel{\circ}{\stackrel{f}{f}}$ & 웅 & ${ }_{\infty}^{\circ}$ & $\stackrel{\circ}{i}$ & 웅 & $\stackrel{\circ}{\underset{f}{f}}$ & $\stackrel{\circ}{+}$ & $\stackrel{\circ}{+}$ & $\stackrel{\circ}{\circ}$ & $\stackrel{\circ}{+}$ & $\stackrel{\circ}{+}$ & $\stackrel{\circ}{\mathrm{i}}$ \\
\hline & $\frac{\pi}{\Sigma}$ & $\stackrel{\circ}{\stackrel{f}{f}}$ & $\underset{+}{\stackrel{\circ}{+}}$ & $\stackrel{\circ}{\stackrel{f}{+}}$ & $\begin{array}{l}0 \\
\infty\end{array}$ & $\stackrel{\leftrightarrow}{\mathrm{i}}$ & $\stackrel{\circ}{+}$ & $\stackrel{\text { O }}{+}$ & 웅 & 字 & $\stackrel{\circ}{\stackrel{\leftrightarrow}{f}}$ & 宅 & 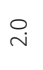 & 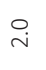 \\
\hline \multirow{2}{*}{$\underline{\underline{\underline{w}}}$} & $\tilde{u}$ & $\stackrel{\stackrel{\sim}{\rightleftharpoons}}{\sim}$ & $\stackrel{\stackrel{\sim}{\simeq}}{\sim}$ & 吕 & $\stackrel{\infty}{\sim}$ & $\stackrel{\sim}{\mathcal{O}}$ & gे & $\stackrel{\infty}{\sim}$ & $\stackrel{\infty}{\sim}$ & 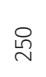 & 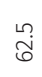 & $\stackrel{\mathscr{N}}{\cong}$ & 吕 & 욤 \\
\hline & $\frac{\pi}{\Sigma}$ & $\stackrel{\stackrel{\llcorner}{\sim}}{\stackrel{m}{m}}$ & $\stackrel{\stackrel{\sim}{\sim}}{\stackrel{m}{m}}$ & $\stackrel{\stackrel{\sim}{\simeq}}{\simeq}$ & $\stackrel{\infty}{\sim}$ & $\stackrel{\stackrel{\llcorner}{\sim}}{\stackrel{m}{m}}$ & ồ & $\stackrel{\llcorner}{\sim}$ & $\vec{m}$ & $\stackrel{\stackrel{\sim}{\tilde{m}}}{\underset{m}{m}}$ & $\stackrel{\infty}{\sim}$ & $\underset{m}{\stackrel{\sim}{m}}$ & $\begin{array}{l}\stackrel{\circ}{\circ} \\
\stackrel{2}{2}\end{array}$ & $\stackrel{\circ}{\stackrel{\circ}{~}}$ \\
\hline \multirow{2}{*}{ t } & $\frac{\pi}{\nu}$ & ' & , & , & , & , & , & , & & ' & & , & & \\
\hline & $\frac{\tilde{U}}{\Sigma}$ & 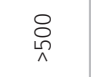 & 只 & 员 & 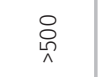 & 各 & 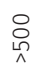 & 总 & 吕 & 总 & 号 & 吕 & 品 & 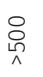 \\
\hline \multirow{2}{*}{$m$} & 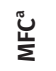 & $\stackrel{\stackrel{\sim}{\simeq}}{ }$ & $\stackrel{\llcorner}{\simeq}$ & $\stackrel{\mathscr{}}{\sim}$ & $\stackrel{\stackrel{\circ}{N}}{ }$ & 怘 & 怘 & 号 & $\stackrel{\stackrel{\sim}{\sim}}{\sim}$ & $\stackrel{\mathscr{Z}}{\approx}$ & 呙 & ' & ' & ' \\
\hline & $\frac{\pi}{\Sigma}$ & $\stackrel{\stackrel{\sim}{\simeq}}{\sim}$ & $\stackrel{\stackrel{\sim}{ }}{\sim}$ & $\stackrel{\llcorner}{\simeq}$ & $\stackrel{\sim}{\mathcal{O}}$ & 品 & $\stackrel{\mathscr{}}{\simeq}$ & 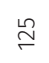 & $\stackrel{\llcorner}{\cong}$ & $\stackrel{\llcorner}{\approx}$ & $\stackrel{\stackrel{\sim}{\sim}}{ }$ & 号 & 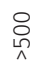 & 号 \\
\hline \multirow{2}{*}{$\bar{N}$} & $\tilde{u}$ & $\stackrel{\stackrel{\sim}{\nsubseteq}}{\simeq}$ & $\stackrel{\stackrel{\sim}{\sim}}{\sim}$ & $\stackrel{\sim}{\underset{O}{0}}$ & $\stackrel{\sim}{\widetilde{\delta}}$ & $\stackrel{\sim}{\sim}$ & $\stackrel{\mathscr{N}}{\sim}$ & $\stackrel{\sim}{\mathcal{O}}$ & & , & 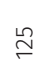 & $\stackrel{\sim}{\text { L }}$ & $\stackrel{\leftrightarrow}{\sim}$ & 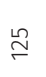 \\
\hline & $\frac{\tilde{U}}{\Sigma}$ & $\stackrel{\llcorner}{\mathcal{O}}$ & $\stackrel{\llcorner}{\mathrm{O}}$ & $\stackrel{\sim}{\text { S్ }}$ & 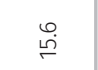 & $\underset{m}{m}$ & 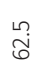 & 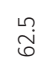 & 呙 & 号 & $\underset{m}{\stackrel{\sim}{m}}$ & $\stackrel{\sim}{m}$ & $\stackrel{\sim}{\mathcal{O}}$ & 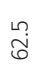 \\
\hline \multirow{2}{*}{$\breve{N}$} & 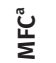 & $\stackrel{\stackrel{\sim}{\simeq}}{\sim}$ & $\stackrel{\stackrel{\sim}{ }}{\sim}$ & 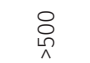 & 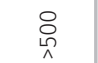 & 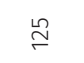 & $\stackrel{\stackrel{\leftrightarrow}{N}}{ }$ & & , & ' & $\stackrel{\circ}{\sim}$ & $\stackrel{\stackrel{\rho}{N}}{ }$ & $\stackrel{\sim}{\sim}$ & $\stackrel{\llcorner}{\sim}$ \\
\hline & $\tilde{\tilde{U}}$ & $\stackrel{\stackrel{\sim}{ }}{\sim}$ & $\stackrel{\stackrel{n}{ }}{\sim}$ & 怘 & $\stackrel{\circ}{\sim}$ & $\stackrel{\llcorner}{\dddot{N}}$ & $\stackrel{\mathscr{Z}}{\cong}$ & 号 & 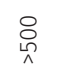 & 总 & 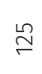 & $\stackrel{\mathscr{}}{\simeq}$ & $\stackrel{\llcorner}{\mathcal{O}}$ & $\stackrel{\mathscr{\sim}}{\cong}$ \\
\hline \multirow{2}{*}{ مิ } & $\frac{\tilde{u}}{\Sigma}$ & 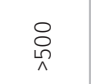 & , & & 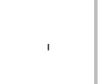 & 品 & 品 & & ' & & 品 & 品 & ' & 足 \\
\hline & $\frac{\pi}{\Sigma}$ & 号 & 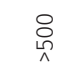 & 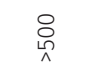 & 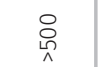 & 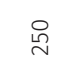 & $\stackrel{\stackrel{\leftrightarrow}{\sim}}{ }$ & 宓 & 号 & 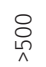 & $\stackrel{\stackrel{\sim}{\sim}}{ }$ & $\stackrel{\circ}{\sim}$ & 各 & $\stackrel{\leftrightarrow}{\sim}$ \\
\hline \multirow{2}{*}{ న } & $\frac{\tilde{u}}{\Sigma}$ & & , & & & $\stackrel{\text { 怘 }}{\text {. }}$ & & & & ' & , & , & , & \\
\hline & $\frac{\pi}{\Sigma}$ & 吕 & 吕 & 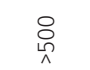 & 号 & 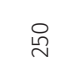 & 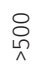 & 总 & 呙 & 各 & 号 & 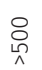 & 号 & 冬 \\
\hline \multirow{2}{*}{-} & 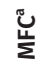 & & $\stackrel{\llcorner}{\mathcal{O}}$ & $\underset{m}{m}$ & $\stackrel{\sim}{m}$ & 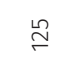 & $\stackrel{\stackrel{\sim}{\sim}}{\sim}$ & $\underset{m}{\tilde{m}}$ & $\stackrel{\llcorner}{\cong}$ & $\underset{m}{\tilde{m}}$ & $\stackrel{\llcorner}{\mathcal{O}}$ & $\underset{m}{\tilde{m}}$ & $\stackrel{\llcorner}{\stackrel{L}{0}}$ & $\stackrel{\overbrace{}}{m}$ \\
\hline & $\frac{\pi}{\Sigma}$ & $\stackrel{\infty}{\sim}$ & $\stackrel{\infty}{\sim}$ & $\stackrel{\sim}{m}$ & $\stackrel{\sim}{m}$ & $\stackrel{\sim}{m}$ & $\stackrel{\infty}{\wedge}$ & $\stackrel{\infty}{\sim}$ & $\stackrel{\infty}{\sim}$ & $\stackrel{\infty}{\stackrel{\infty}{\sim}}$ & $\stackrel{\infty}{\sim}$ & $\stackrel{\infty}{\stackrel{\infty}{\sim}}$ & $\stackrel{\infty}{\sim}$ & $\stackrel{\infty}{\sim}$ \\
\hline 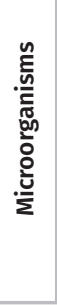 & & 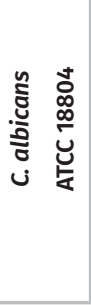 & 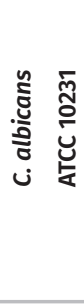 & 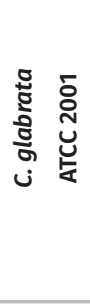 & 总 & 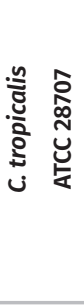 & ป & ปี & $\stackrel{m}{\mathcal{U}}$ & さ & ? & Uి & ป & $\stackrel{\infty}{త}$ \\
\hline
\end{tabular}


validating our experimental conditions. This fungicidal effect is relevant because the rapid elimination of microorganisms prevents the spread of pathogens and disease progression, guaranteeing the success of the treatment (Nóbrega et al. 2013, Ling et al. 2015, Andrade et al. 2018). Thus, the fungicidal effect of compound 1 is pharmacologically important and desirable in the search for new antifungal drugs.

The use of anti- C. albicans agents in combination may be more promising than such compounds used alone (Zida et al. 2016). In this context, the antifungal activity of alkaloid 1 was evaluated after its combination with the imidazole ketoconazole and the polyene nystatin by the checkboard assay. The results showed that compound 1 has a synergistic interaction with ketoconazole ( $\mathrm{FICl}$ 0.27) and additive with nystatin ( $\mathrm{FICl}$ 0.7) (Table II). These results suggest that this compound can be used in combination with imidazole antifungals (e.g., ketoconazole) to enhance its therapeutic effect. These findings are significant because drug combinations are often recommended since they may allow a

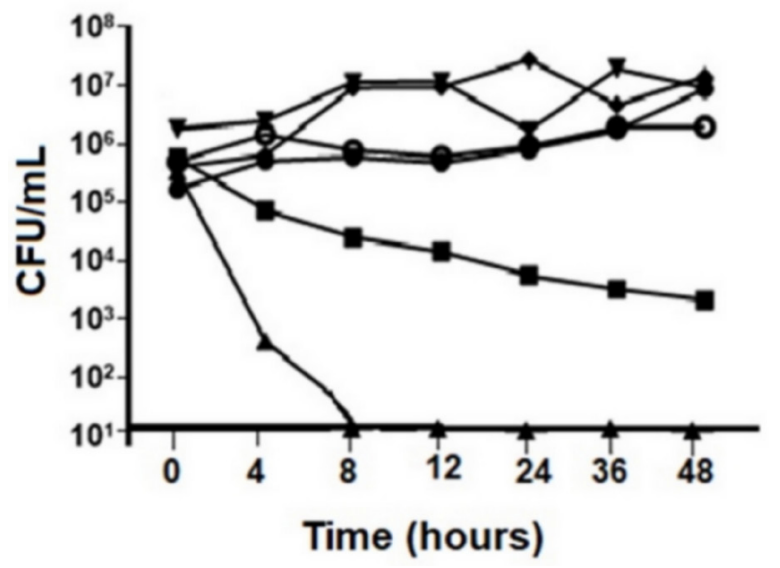

Figure 2. Time-kill curve assay of alkaloid 1 against Candida albicans ATCC 10231. Compound 1 was evaluated at $7.8 \mu \mathrm{g} / \mathrm{mL}(-), 31.25 \mu \mathrm{g} / \mathrm{mL}(*)$, and $62.5 \mu \mathrm{g} / \mathrm{mL}(-)$. Ketoconazole $(125 \mu \mathrm{g} / \mathrm{mL} ;-)$ was employed as the positive control, DMSO $(v / v<2 \% ;-\infty)$ was employed as vehicle control, and untreated fungal cells as growth control ( $\left.\boldsymbol{*}^{-}\right)$. considerable reduction in the concentration of the drug, minimizing the side effects and the final cost of the treatment (Carvalho et al. 2018b).

Next, the effects on the fungal membrane and cell wall were evaluated for alkaloid 1 against $C$. albicans. The damage observed in the fungal cells was not associated with the binding of compound 1 to the membrane ergosterol because the MIC value with exogenous ergosterol remained unchanged for all species evaluated. The antifungal activity of nystatin, which acts on the fungal membrane through ergosterol binding, decreased in the presence of exogenous ergosterol for all species tested, validating our experimental conditions (Table III). Furthermore, no increase in the MIC value was observed for all species evaluated in the presence of sorbitol (Table III), a substance that acts as an osmotic protector of the fungal cell wall (Andrade et al. 2018). Caspofungin, a drug with a mechanism of action associated with structural alterations of the fungal cell wall, showed an increase in the MIC after sorbitol supplementation, validating the experimental conditions employed in this study. Thus, the action of alkaloid 1 on fungal cell components remains to be determined in future studies.

Yeast-to-hyphal transition is a key in the pathophysiology of invasive candidiasis (Pappas et al. 2018, Lima et al. 2019). Thus, the effect of the most promising alkaloid (1) was evaluated against this important virulence factor of $C$. albicans. This compound at $15.6 \mu \mathrm{g} / \mathrm{mL}$ reduced the $\mathrm{Y}-\mathrm{H}$ transition, and the data were confirmed over $72 \mathrm{~h}$ (Figure 3). In the absence of treatment (growth control), the $\mathrm{Y}-\mathrm{H}$ transition was observed, but it was affected by the treatment with ketoconazole $(125 \mu \mathrm{g} / \mathrm{mL})$, a reference drug used as control positive. In addition, DMSO v/v $<2 \%$, used as solvent control, did not inhibit $\mathrm{Y}-\mathrm{H}$ transition, validating the conditions employed. 
To the best of our knowledge, this is the first time that a total reduction in the $\mathrm{Y}-\mathrm{H}$ transition by the treatment with a synthetic alkaloid is reported. This finding is significant since the yeast-to-hyphal morphogenetic switch plays a vital role in the transition from candidemia to the subsequent tissue invasion (Richardson \& Warnock 1997, Kornitzer 2019). Moreover, the establishment of candidemia might also be favored by the enhanced ability of the hyphae to penetrate the mucous membranes and underlying tissues and enter the bloodstream (Koh et al. 2008). In addition, hyphae formation in the phagosome was shown to contribute to the ability of $C$. albicans cells to escape phagocytosis and kill the macrophage (Marcil et al. 2002, Ghosh et al. 2009, McKenzie et al. 2010). In this context, the ability of compound 1 to inhibit $\mathrm{Y}-\mathrm{H}$ transition in Candida albicans may contribute not only to its direct antifungal activity but also to potentiate the host antifungal immune response.

Finally, the safety of alkaloid 1 was assessed through the cytotoxicity assay in mammalian renal cells (BHK-21 and Vero strains). Compound 1 presented a $\mathrm{CC}_{50}$ of $36.61 \pm 8.30 \mu \mathrm{g} / \mathrm{mL}$ and $7.78 \pm 0.1060 \mu \mathrm{g} / \mathrm{mL}$ against BHK-21 and Vero cells, respectively. Ketoconazole was also considerably cytotoxic, showing a $\mathrm{CC}_{50}$ of $42.48 \pm 1.16 \mu \mathrm{g} /$ $\mathrm{mL}$ and $10.31 \pm 0.60 \mu \mathrm{g} / \mathrm{mL}$ for Vero and
Table II. Fractional inhibitory concentration index (FICl) obtained from combinations of alkaloid 1 and ketoconazole or nystatin against Candida albicans ATCC 10231.

\begin{tabular}{|c|c|c|}
\hline Antifungal & FICl & Effect \\
\hline & alkaloid 1 & \\
\hline Ketoconazole & 0.27 & Synergistic \\
\hline Nystatin & 0.7 & Additive \\
\hline
\end{tabular}

BHK-21 cells, respectively. The selectivity index (SI) of compound 1 to different Candida species regarding BHK-21 and Vero cells is shown in Table IV. The SI of compound 1 ranged from 0.25 to 4.69, in which the higher SI value was observed for C. albicans ATCC 10231 (IS 4.69), which is a fluconazole-resistant strain (Lima et al. 2019). However, ketoconazole, a reference antifungal widely used in clinical practice, showed larger SI values (0.25-37.4 for both cell lines).

An important limitation for the use of alkaloids is their high cytotoxicity, which has already been described in another study (Barbosa et al. 2018). Thus, the main challenge for the development of new antifungals is related to the fact that both fungi and human cells are eukaryotic, making it challenging to identify specific metabolite targets and fungal structures, which results in the high toxicity of antifungal agents (Morace et al. 2014, Andrade et al. 2018).

Table III. Action of alkaloid 1 on membrane and cell wall of four Candida spp.

\begin{tabular}{|c|c|c|c|c|c|c|c|c|c|c|c|c|}
\hline & \multicolumn{12}{|c|}{$\operatorname{MIC}(\mu \mathrm{g} / \mathrm{mL}) *$} \\
\hline & \multicolumn{3}{|c|}{ C. albicans ATCC 10231} & \multicolumn{3}{|c|}{ C. glabrata ATCC 2001} & \multicolumn{3}{|c|}{ C. krusei ATCC 34135} & \multicolumn{3}{|c|}{ C. tropicalis ATCC 28707} \\
\hline & MIC & $\begin{array}{l}\text { MIC with } \\
\text { Ergosterol }\end{array}$ & $\begin{array}{l}\text { MIC with } \\
\text { Sorbitol }\end{array}$ & MIC & $\begin{array}{l}\text { MIC with } \\
\text { Ergosterol }\end{array}$ & $\begin{array}{c}\text { MIC } \\
\text { with } \\
\text { Sorbitol }\end{array}$ & MIC & $\begin{array}{l}\text { MIC with } \\
\text { Ergosterol }\end{array}$ & $\begin{array}{l}\text { MIC with } \\
\text { Sorbitol }\end{array}$ & MIC & $\begin{array}{l}\text { MIC with } \\
\text { Ergosterol }\end{array}$ & $\begin{array}{c}\text { MIC } \\
\text { with } \\
\text { Sorbitol }\end{array}$ \\
\hline 1 & 7.8 & 7.8 & 7.8 & 31.25 & 31.25 & 31.25 & 31.25 & 31.25 & 31.25 & 31.25 & 31.25 & 31.25 \\
\hline NIS & 4.0 & 31.25 & ND & 4.0 & 31.25 & ND & 8.0 & 31.25 & ND & 2.0 & 3.9 & ND \\
\hline CSP & 4.0 & ND & 15.6 & 0.5 & ND & 1.0 & 0.0625 & ND & 0.25 & 0.0625 & ND & 0.25 \\
\hline
\end{tabular}

*Values are the average of three readings. NIS: Nistatin; CSP: Caspofungin. ND: Not determined. 
However, the safety assessment of compounds of pharmaceutical interest by the in vitro cytotoxicity assay is preliminary, and these results do not eliminate the potential of analog 1 as a prototype for prospecting new antifungal drugs (Mokoka et al. 2013). Importantly, cytotoxicity is not the only factor to be considered in determining the therapeutic potential of a compound. For example, amphotericin B, a widely used polyene in clinical practice, presents high cytotoxic activity against microglia cell line
(Klepser 2011) and known nephrotoxic effect in humans (Mayer et al. 2013). Thus, it is noteworthy that complementary assays, such as evaluation of acute toxicity in mice, are necessary to better elucidate the toxicity of alkaloid 1.

\section{CONCLUSIONS}

In conclusion, seven 3-alkylpyridine alkaloid analogs were synthesized and described. The results indicate that the alkaloid 1

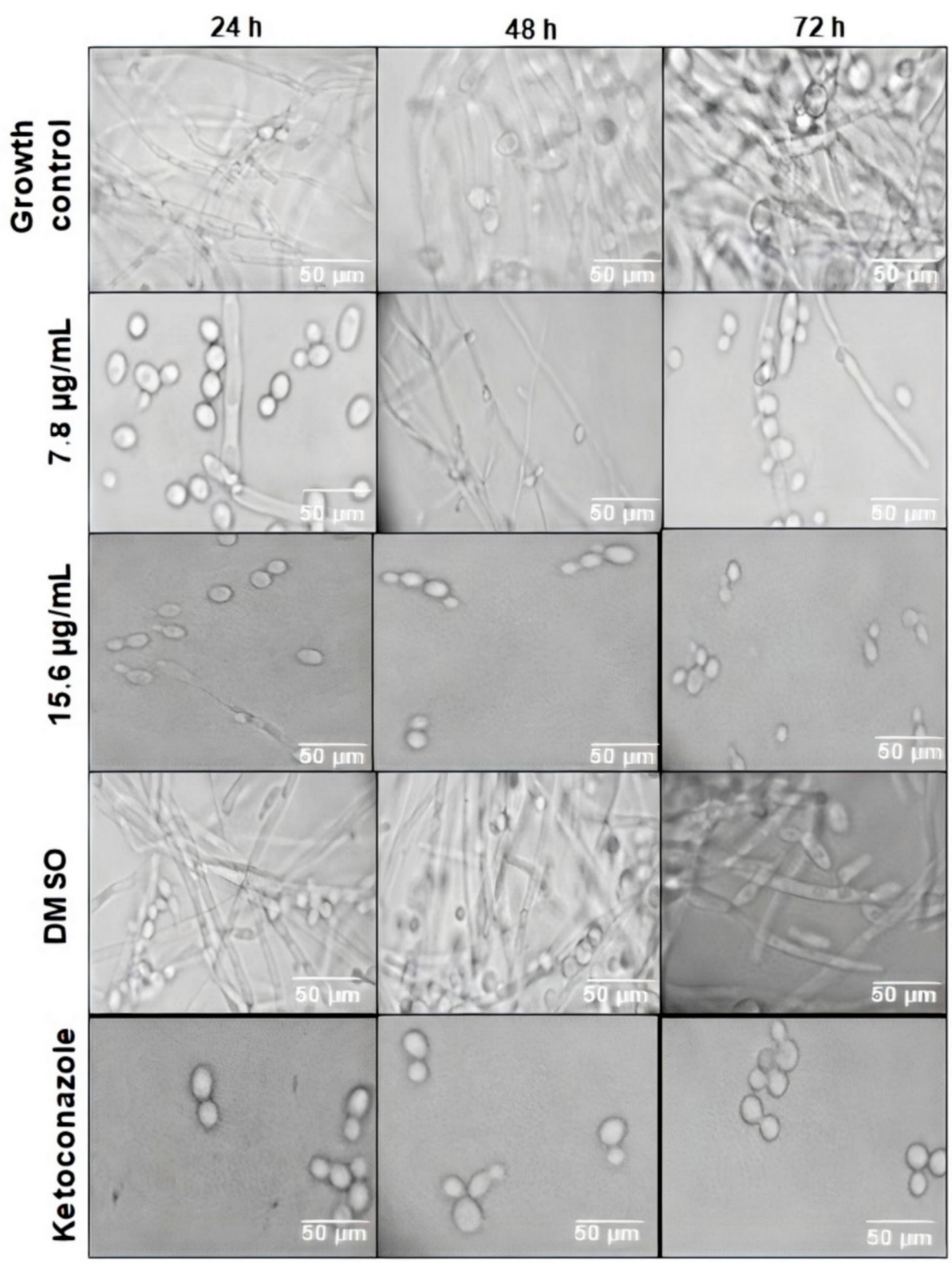

Figure 3. Hyphae formation of Candida albicans ATCC 10231. Candida albicans cells were cultured with alkaloid 1 (7.8 and $15.6 \mu \mathrm{g} / \mathrm{mL}$ ) for 24,48 , and $72 \mathrm{~h}$ at $37^{\circ} \mathrm{C}$. Ketoconazole was used as the positive control and DMSO as vehicle control. The experiments were performed in duplicate and repeated three times. Representative microphotographs are shown. The white bar represents a length of $50 \mu \mathrm{m}$ (magnification of $\times 400)$. 
showed promising fungistatic and fungicidal activity against Candida species, which was independent of its capacity of binding to the membrane ergosterol or fungal cell wall. The fungicidal effect was confirmed by the time-kill curve study, with a maximum fungicidal effect after 8 h. Furthermore, compound 1 interacts synergistically with ketoconazole ( $\mathrm{FICl} 0.27$ ). We also showed that this compound is associated with a total reduction in the $\mathrm{Y}-\mathrm{H}$ transition of C. albicans. However, it presented considerable cytotoxicity in vitro against mammalian cells with low SI values. In summary, alkaloid 1 stands out as a promising prototype in the development of new effective drugs against Candida spp. However, molecular modifications of this compound are encouraged to reduce its toxicity and potentiate the antifungal effect.

\section{Acknowledgments}

We would like to thank the Universidade Federal de São João del-Rei, Conselho Nacional de Desenvolvimento Científico e Tecnológico (CNPq), Coordenação de Aperfeiçoamento de Pessoal de Nivel Superior (CAPES), and Fundação de Amparo à Pesquisa do estado de Minas Gerais (FAPEMIG) by financial support. Jessica T. Andrade and William G. Lima are grateful to UFSJ and CAPES for a Ph.D. fellowship, respectively. We also thank Professor Ph.D. Marcelo Gonzaga de Freitas Araújo (Laboratório de Farmacologia da Dor e Inflamação, Universidade Federal de São João Del Rei, Divinópolis, Brazil) for providing the ergosterol used in the phenotypic studies.

\section{REFERENCES}

ANDRADE JT, SANTOS FRS, LIMA WG, SOUSA CDF, OLIVEIRA LSFM, RIBEIRO RIMA, GOMES AJPS, ARAÚJO MGF, VILLAR JAFP \& FERREIRA JM. 2018. Design, synthesis, biological activity and structure activity relationship studies of chalcone derivatives as potential anti-Candida agents. J Antibiot 1: 1-11.

Table IV. Selective index (SI) of alkaloid 1 and ketoconazole to different Candida species regarding BHK-21 and Vero cells.

\begin{tabular}{|c|c|c|c|c|}
\hline \multirow{2}{*}{ Microorganisms } & \multicolumn{2}{|c|}{1} & \multicolumn{2}{|c|}{ Ketoconazole } \\
\hline & Vero & BHK-21 & Vero & BHK-21 \\
\hline C. albicans ATCC 18804 & 1.00 & 4.69 & 0.25 & 1.17 \\
\hline C. albicans ATCC 10231 & 1.00 & 4.69 & 0.25 & 1.17 \\
\hline C. glabrata ATCC 2001 & 0.25 & 1.17 & 0.06 & 0.29 \\
\hline C. krusei ATCC 34135 & 0.25 & 1.17 & 1.00 & 4.69 \\
\hline C. tropicalis ATCC 28707 & 0.25 & 1.17 & 0.25 & 1.17 \\
\hline CL1 & 1.00 & 4.69 & 8.02 & 37.74 \\
\hline CL2 & 1.00 & 4.69 & 3.99 & 18.77 \\
\hline CL3 & 1.00 & 4.69 & 1.99 & 9.39 \\
\hline CL4 & 1.00 & 4.69 & 0.25 & 1.17 \\
\hline CL5 & 1.00 & 4.69 & 1.00 & 4.69 \\
\hline CL6 & 1.00 & 4.69 & 0.25 & 1.17 \\
\hline CL7 & 1.00 & 4.69 & 0.50 & 2.35 \\
\hline CL8 & 1.00 & 4.69 & 0.50 & 2.35 \\
\hline Overall mean & 0.82 & 3.88 & 1.41 & 6.63 \\
\hline
\end{tabular}

\footnotetext{
Selectivity index $(\mathrm{SI})$ is a ration of $\mathrm{CC}_{50}$ to MICs values. CL1-CL-5: Oral isolates; CL6-CL8: Vaginal isolates.
} 
ARAÚJO MGF, PACÍFICO M, VILEGAS W, SANTOS LC, ICELY PA, MIRÓ MS, SCARPA MVC, BAUAB TM \& SOTOMAYOR CE. 2013. Evaluation of Syngonanthusnitens (Bong.) Ruhl. extract as antifungal and in treatment of vulvovaginal candidiasis. Med Mycol 1: 1-10.

BARBOSA MCS ET AL. 2018. Synthesis and evaluation of the mutagenicity of 3-alkylpyridine marine alkaloid analogues with anticancer potential. Mutat Res Toxicol Environ Mutagen 825: 31-39.

BONGOMIN F, GAGO S, OLADELE R \& DENNING D. 2017. Global and Multi-National Prevalence of Fungal DiseasesEstimate Precision. J Fungi: 3: 57.

CARVALHO RS, CAROLLO CA, MAGALHÃES JC, PALUMBO JMC, BOARETTO AG, NUNES IC, FERRAZ AC, LIMA WG, SIQUEIRA JM \& FERREIRA JMS. 2018a. Antibacterial and antifungal activities of phenolic compound-enriched ethyl acetate fraction from Cochlospermum regium (mart. Et. Schr.) Pilger roots: mechanisms of action and synergism with tannin and gallic acid, S Afr J Bot 114: 181-187.

CARVALHO RR, SILVA NC, CUSINATO M, DIAS KST, SANTOS MH, VIEGAS JUNIOR C, SILVA EG \& DIAS ALT. 2018b. Promising synergistic activity of fluconazole with bioactive Guttiferone-A and derivatives against non-albicans Candida species. J Mycol Med 28: 645-650.

CLSI - CLINICAL AND LABORATORY STANDARDS INSTITUTE. 2008. Reference method for broth dilution antifungal susceptibility testing of yeasts, $3^{\text {rd }}$ ed., Approved standard M27-A3, Wayne, PA.

DAI L, JACOB MR, JHAN SI, KHAN IA, CLARK AM \& XING-CONF L. 2011. Synthesis and Antifungal Activity of Natural Product-Based 6-Alkyl-2,3,4,5-tetrahydropyridines. J Nat Prod 74: 2023-2026.

ESCALANTE A, GATTUSO M, PEREZ P \& ZACCHINO S. 2008. Evidence for the Mechanism of Action of the Antifungal Phytolaccoside B Isolated from Phytolacca tetramera Hauman. J Nat Prod 71: 1720-1725.

FALAGAS ME, ROUSSOS N \&VARDAKAS KZ. 2010. Relative frequency of albicans and the various non-albicans Candida spp among candidemia isolates from inpatients in various parts of the world: A systematic review. Int J Infect Dis 4: 954-966.

FRENZ JF, KOHL AC \& KERR RG. 2004. Marine natural products as therapeutic agents. Expert Opin Ther Pat 14: 17-33.

FYHRQUIST P, VIRJAMO V, HILTUNEN E \& JULKUNEN-TIITTO R. 2017. Epidihydropinidine, the main piperidine alkaloid compound of Norway spruce (Picea abies) shows promising antibacterial and anti-Candida activity. Fitoterapia 117: 138-146.

GHOSH S, NAVARATHNA DHMLP, ROBERTS DD, COOPER JT, ATKIN AL, PETRO TM \& NICKERSON KW. 2009. Arginine-Induced germ tube formation in Candida albicans is essential for escape from murine macrophage line RAW 264.7. Infect Immun 77: 1596-1605.

GONÇALVES AMN ET AL. 2014. Synthesis and Biological Evaluation of Novel 3-Alkylpyridine Marine Alkaloid Analogs with Promising Anticancer Activity. Mar Drugs 12: 4361-4378.

HAWSER S \& ISLAM K. 1999. Comparisons of the effects of fungicidal and fungistatic antifungal agents on the morphogenetic transformation of Candida albicans. J Antimicrob Chemother 43: 411-413.

HERRERA KMS, DA SILVA FK, LIMA WG, BARBOSA CS, GONÇALVES AMMN, VIANA GHR, SOARES AC \& FERREIRA JMS. 2020. Antibacterial and antibiofilm activities of synthetic analogs of 3-alkylpyridine marine alkaloids. Med Chem Res 29: 1084-1089.

HILÁRIO FF, PAULA RC, SILVEIRA MLT, VIANA GHR, ALVES RB, PEREIRA JRCS, SILVA LM, FREITAS RP \& VAROTTI FP. 2011. Synthesis and evaluation of antimalarial activity of oxygenated 3-alkylpyridine marine alkaloid analogues. Chem Biol Drug Des 78: 477-482.

KAUFFMAN CA. 2006. Fungal infections. Proc Am Thorac Soc 3: 35-40.

KLEPSER M. 2011. The value of amphotericin B in the treatment of invasive fungal infections. J Crit Care 26: 225-235.

KOH AY, KOHLER JR, COGGSHALL KT, VAN ROOIJEN N \& PIER GB. 2008. Mucosal damage and neutropenia are required for Candida albicans dissemination. PLoS Pathog 4: e35.

KORNITZER D. 2019. Regulation of Candida albicans Hyphal Morphogenesis by Endogenous Signals. J Fungi 5: 1-21.

LIMA WG, ALVES-NASCIMENTO LA, ANDRADE JT, VIEIRA L, RIBEIRO RIMA, THOMÉ RG, SANTOS HB, FERREIRA JMS \& SOARES AC. 2019. Are the Statins promising antifungal agents against invasive candidiasis? Biomed Pharmacother 111: 270-281.

LING LL ET AL. 2015. New antibiotic kills pathogens without detectable resistance. Nature 517: 455-473.

LYU Y, YANG Y, DONG N \& SHAN A. 2016. Antimicrobial activity, improved cell selectivity and mode of action of short PMAP-36-derived peptides against bacteria and Candida. Sci Rep 6: 1-12.

MARCIL A, HARCUS D, THOMAS DY \& WHITEWAY M. 2002. Candida albicans killing by RAW 264.7 mouse macrophage cells: 
Effects of Candida genotype, infection ratios, and gamma interferon treatment. Infect Immun Infect Immun 70: 6319-6329.

MAYER FL, WILSON D \& HUBE B. 2013. Candida albicans pathogenicity mechanisms. Virulence 4: 119-128.

MCKENZIE CG, KOSER U, LEWIS LE, BAIN JM, MORA-MONTES HM, BARKER RN, GOW NA \& ERWIG LP. 2010. Contribution of Candida albicans cell wall components to recognition by and escape from murine macrophages. Infect Immun 78: 1650-1658.

MOKOKA TA, MCGAW LJ, MDEE LK, BAGLA VP \& IWALEWA EO. 2013. Antimicrobial activity and cytotoxicity of triterpenes isolated from leaves of Maytenusundata (Celastraceae). BMC Complem Altern M 13: 1-9.

MORACE G, PERDONI F \& BORGHI E. 2014. Antifungal drug resistance in Candida species. J Glob Antimicrob R 2: 254-259.

NÓBREGA HN, FERREIRA JAB, ROMÃO CMCPA \& CAPASSO IRVF. 2013. Atividade antimicrobiana in vitro de produtos antissépticos por meio de técnica time kill. Rev Inst Adolfo Lutz 72: 226-233.

PAPPAS PG, LIONAKIS MS, ARENDRUP MC, OSTROSKY-ZEICHNER L \& KULLBERG BJ. 2018. Invasive candidiasis. Nat Rev Dis Primers 4: 18026.

PAPPAS PG ET AL. 2016. Clinical practice guideline for the management of candidiasis: 2016 update by the infectious diseases society of America. Clin Infect Dis 62: 1-50.

PERNAK J, KALEWSKA J, KSYCINSKA H \& CYBULSKI J. 2001. Synthesis and antimicrobial activities of some pyridinium salts with alkoxymethyl hydrophobic group. Eur J Med Chem 36: 899-907.

PFALLER MA \& DIEKEMA DJ. 2007. Epidemiology of invasive candidiasis: A persistent public health problem. Clin Microbiol Rev: 20: 133-163.

PFALLER MA \& DIEKEMA DJ. 2010. Epidemiology of invasive mycoses in North America. Crit Rev Microbiol 36: 1-53.

PFALLER M, NEOFYTOS D, DIEKEMA D, AZIE N, MEIER-KRIESCHE HU, QUAN SP \& HORN D. 2012. Epidemiology and outcomes of candidemia in 3648 patients: Data from the Prospective Antifungal Therapy (PATH Alliance(R)) registry, 20042008. Diagn Microbiol Infect Dis 74: 323-331.

RANE RA, GUTTE SD \& SAHU NU. 2012. Synthesis and evaluation of novel 1,3,4-oxadiazole derivatives of marine bromopyrrole alkaloids as antimicrobial agente. Bioorg Med Chem Lett 22: 6429-6432.
RICHARDSON MD \& WARNOCK DW. 1997. Fungal InfectionDiagnosis and Management, $2^{\text {nd }}$ ed., Blackwell Sciences Ltd.: Oxford, UK.

SOUZA MA ET AL. 2013. The antimicrobial activity of lapachol and its thiosemicarbazone and semicarbazone derivatives. Mem Inst Oswaldo Cruz 108: 342-351.

TWENTYMAN RP \& LUSCOMBE M. 1987. A study of some variables in a tetrazolium dye (MTT) based assay for cell growth and chemosensitivity. Br J Cancer 56: 279-285.

VIANA GHR. 2008. Estudos para a síntese da viscosaminsa, de análogos oxigenados e de novos sais de piridínio quirais usando a reação de zincke, 186 p.

VIANA RMR, BUTERA AP, SANTOS ES, TISCHER CA, ALVES RB, FREITAS RP, GUIMARÃES L, VAROTTI FP, VIANA GHR \& NASCIMENTO CS. 2016. Revealing the Binding Process of New 3-Alkylpyridine Marine Alkaloid Analogue Antimalarials and the Heme Group: An Experimental and Theoretical Investigation. J Chem Inf Model 56: 571-579.

WANG G. 2006. Diversity and biotechnological potential of the sponge-associated microbial consortia. J Ind Microbiol Biot 33: 545-551.

WONG SSW, KAO RYT, YUEN KY, WANG Y, YANG D, SAMARANAYAKE LP \& SENEVIRATNE CJ. 2014. In vitro and in vivo activity of a novel antifungal small molecule against Candida infections. Plos one 9: e85836.

ZIDA A, BAMBA S, YACOUBA A, OUEDRAOGO-TRAORE R \& GUIGUEMDÉ RT. 2016. Anti-Candida albicans natural products, sources of new antifungal drugs: A review. J Mycol Med 27: 1-19.

ZORE GB, THAKRE AD, JADHAV J \& KARUPPAYIL SM. 2011. Terpenoids inhibit Candida albicans grow by affecting membrane integrity and arrest od cell cycle. Phytomedicine 18: 1181-1190.

\section{How to cite}

ANDRADE JT, LIMA WG, BARBOSA CS, GONÇALVES AMMN, SILVA MKP, MORAIS FB, PALUMBO JMC, VIANA GHR \& FERREIRA JMS. 2021. Antifungal activity of a novel 3-Alkylpyridine analog derived from Marine sponge alkaloids. An Acad Bras Cienc 93: e20200944. DOI 10.1590/00013765202120200944.

Manuscript received on June 16, 2020;

accepted for publication on August 5, 2021 
JÉSSICA T. ANDRADE ${ }^{1}$

https://orcid.org/0000-0002-0705-4090

WILLIAM G. LIMA ${ }^{1,3}$

https://orcid.org/0000-0001-8946-9363

CAMILA S. BARBOSA ${ }^{2}$

https://orcid.org/0000-0001-9631-3172

ALESSANDRA M.M.N. GONÇALVES ${ }^{2}$

https://orcid.org/0000-0002-6838-1781

MAYRA K.P. SILVA ${ }^{1}$

https://orcid.org/0000-0001-5784-4181

FERNANDA B. MORAIS ${ }^{1}$

https://orcid.org/0000-0003-3051-9914

\section{JULIANA M.C. PALUMBO ${ }^{1}$}

https://orcid.org/0000-0002-8607-9711

\section{GUSTAVO H.R. VIANA ${ }^{2}$}

https://orcid.org/0000-0002-1521-7486

\section{JAQUELINE M.S. FERREIRA ${ }^{1}$}

https://orcid.org/0000-0002-1779-1975

${ }^{1}$ Universidade Federal de São João Del-Rei/UFSJ, Laboratório de Microbiologia Médica, Campus Centro Oeste Dona Lindu, Av. Sebastião Gonçalves Coelho, Chanadour, 400, 35501-296 Divinópolis, MG, Brazil ${ }^{2}$ Universidade Federal de São João Del-Rei/UFSJ, Laboratório de Síntese Orgânica, Campus Centro Oeste Dona Lindu, Av. Sebastião Gonçalves Coelho, Chanadour, 400, 35501-296 Divinópolis, MG, Brazil

${ }^{3}$ Universidade Federal de Minas Gerais, Departamento de Produtos Farmacêuticos, Faculdade de Farmácia, Avenida Presidente Antônio Carlos, 6627, 34096-830 Belo Horizonte, MG, Brazil
Correspondence to: Jéssica Tauany Andrade

E-mail: jessicatauany@gmail.com

\section{Author contributions}

JMSF and GHRV conceived, designed, and coordinated the research. JTA, WGL, CSB, AMMNG, MKPS, FBM, and JMCP conducted the experiments. All authors discussed the results and contributed to the final manuscript.

\section{(cc) BY}

